\title{
The Constitutional Interpretation on the Natural Resource: Originalist Vs Non-Originalist Interpretation
}

\author{
Herdiansyah Hamzah
}

Faculty of Law, Mulawarman University, Indonesia. E-mail: herdihamzah@gmail.com

\begin{tabular}{l} 
ARTICLE INFO \\
\hline Keywords: \\
Constitutional Court; \\
Constitutional \\
Interpretation; \\
Interpretation; Natural \\
Resource \\
How to cite: \\
Hamzah, H. (2019). The \\
Constitutional \\
Interpretation on the \\
Natural Resource: \\
Originalist Vs Non- \\
Originalist Interpretation, \\
Hasanuddin Law Review, \\
5 (3): 299-310 \\
DoI: \\
10.20956/halrev.v5i3.2022
\end{tabular}

\section{Introduction}

The constitutional court is an institution responsible for controlling product legalization as not having contradiction with the constitution (judicial control). According to Maurice Duveger quoted by Ni'matul Huda dan R. Nazriyah, judicial control is essential in order to maintain the law regulation agrees with the constitution. The constitution will lose its principle of justice and only becomes series of 
meaningless words if there are no institutions responsible for guarding and maintaining the value of law formulated within. In addition, control toward action done by executive legislation is aiming at ensuring that the executive legislation is not breaking the law. ${ }^{1}$

The authority of constitutional court covers four fundamental disciplines which explicitly stated in section $24 \mathrm{C}$ verse 1 in the Constitution of the Republic of Indonesia year 1945; examining the laws in constitution, interrupting legal dispute of state institution mandated based on the constitution, deciding the dispersal of political parties and solving the disagreement on general election's final decision. In addition, the constitution court is also responsible for verifying, administering justice and deciding whether president or vice president is breaking the law in terms of betraying the state, supporting corruption, doing bribery, having another criminal act, displaying contempt of court, or both president and vice president are no longer meeting the qualification needed. In order to maintain the dignity of constitution, the judges in constitutional court are supported by proper ability on interpreting the constitution, so that there is balance between what has formulated in the constitution (constitutional text) with future decision made by the constitutional court (constitutional adjudication). Scientifically, the whole society also needs to understand and comprehend well the way judges in constitutional court interpret the constitution. Regarding to the interpretation of constitution on natural resource, constitutional judges use method and form of interpretation by which they represent both the judges and the decisions made.

Generally, the constitutional interpretation on natural resource is closely related to the view of constitutional court on the management of natural resource constituent rooted in the Constitution of the Republic of Indonesia year 1945. In sum, this article will focus on two major discussions: first, how is the method used by the constitutional court to examine the law products toward the Constitution of the Republic of Indonesia year 1945? This formulation will simply explain the method used by the constitutional court to test the existed constitution. Second, how is the constituional interpretation on natural resource? The second formulation will try to compare by questioning whether there is any specific and different perspective in interpreting the law products on the field of natural resource with products of constitution on another fields.

\section{Constitutional Interpretation Method}

The interpretation is closely attached with the act finding (rechtsvinding). According to Achmad Ali, there are two act finding theories that can be used by judges in doing their judicial practices, they are interpretation and construction. Basically, European continental jurist had not strictly differentiated between intention method and construction method. Opposed to that, Anglo Saxon jurist clearly separated both methods ${ }^{2}$. Sudikno Mertokusumo stated that interpretation is one method of act finding where it can open comprehensive explanation about the constitution's text so that range of convention can be made in accordance with a particular situation. Interpretation made by judges has to be an explanation that practically acceptable for

\footnotetext{
1 Ni'matul Huda dan R. Nazriyah. (2011). Teori E Pengujian Peraturan Perundang-Undangan. Bandung : Penerbit Nusa Media, p. 127.

2 Ahmad Ali. (1993). Menguak Tabir Hukum (Suatu Kajian Filosofis dan Sosiologis). Candra Pratama : Jakarta, p. 167.
} 
the society regarding to the law used in concrete event. ${ }^{3}$ According to Gadamer as quoted by Ahmad Rifai stated:4

Legal hermeneutics is, then, in reality no spesial case but is, on the contrary, fitted to restore the full scope of the hermeneutical problem and so to restrieve the former unity of hermeneutics, in which jurist and theologian meet the student of the humanities.

In summary, hermeneutics can be claimed as the art of text's interpretation. Thus, hermeneutics law may mean as the art of interpreting text on law or similar with it. Lieber, on the other hand, stated that hermeneutics is a branch of science discussing about the principle and rule of interpretation and construction. The term "hermeneutics" itself, comes from Greek which means running an interpretation and thus it is the opposite of "eksegesis", which also generated from Greek, which means explanation. Therefore, comparing hermeneutics with eksegesis is similar to comparing theory with practical ${ }^{5}$. Hermeneutics has a major role in terms of formulating series of basic or general principles on interpretation and construction. In hermeneutics context, interpretation and construction are two different entities. Fish, as quoted by Soetandyo in Otje Salma and Anton F. Susanto, said that hermeneutics approach has to be an engagement for people to always question social fact and legal fact through interpretation, in fact, the only thing to know about interpretation is that it has to be done every time. Adding to this, the law wishes to have a formal existence"6, does it?

Generally, hermeneutics defines as a theory or philosophy about meaning and its interpretation. Hermeneutics derived from Greek's verb "hermeneuien", which means interpreting or translating. If the word "hermeneutics" is rearranged from its origin, this word is derived from the word "hermes" (hermeios), a goddess from Greek's mythology whose duty was to explain and send down messages from god to humankind. Hermes was supposed to interpret or translate messages into language spoken by the hearer?

According to Lieber, interpretation is an effort to find and display the true meaning from any signs used to express ideas. "The true meaning" here means the desired meaning by which people show expression using the code ${ }^{8}$. Lieber formulated nine basic interpretations listed as follows:

a. A sentence, or form of words, has only one true meaning.

b. There is no salutary interpretation without divine belief and logic.

c. In sum, words are those as which it is probably well comprehended by the speaker. On doubtful cases, we seek meaning from what is common instead of from grammatical or classical meaning, understanding technical meaning instead of etymologic meaning as the so called "verba artis ex arte". Words are commonly understood regarding to what meets the character of text the most along with its speaker. Thing which is inferior and specific cannot overtaken thing which is superior and common. The exception (for number 4) based on what is superior.

\footnotetext{
3 Sudikno Mertokusumo. (2002). Mengenal Hukum (Suatu Pengantar). Liberty : Yogyakarta, p. 154.

4 Ahmad Rifai. (2010). Penemuan Hukum Oleh Hakim Dalam Perspektif Hukum Progresif. Sinar Grafika : Jakarta, p. 87.

5 Gregory Leyh, et all. (2008). Hermeneutika Hukum. Penerbit Nusa Media : Bandung, p. 127.

6 Otje Salman dan Anthon F. Susanto. (2005). Teori Hukum (Mengingat, Mengumpulkan dan Membuka Kembali). PT. Refika Aditama : Bandung, p. 82.

7 Anthon F. Susanto. (2010). Ilmu Hukum Non Sistematik, Fondasi Filsafat Pengembangan Ilmu Hukum Indonesia. Genta Publishing : Yogyakarta, p. 109-110.

8 Gregory Leyh, et all (2008). Op.Cit, p. 141.
} 
d. What is possible, suitable and common are ahead compared to what is impossible, unsuitable and uncommon.

e. We follow particular rules given by the right authority.

f. We seek for help based on what is near to us instead of what is far.

g. Interpretation is not a goal but it is a tool; higher conditions are possibly occurred. ${ }^{9}$

In addition to that, Lieber posited that construction is a process of making conclusion on the main topic hidden behind direct expression of text from elements found in text a conclusion remark within spirit which is unrelated with letters built in text.

The interpretation on law needs to be precise in order to avoid misunderstanding in the interpretation itself. According to Sudikno Mertokusumo, the interpretation done by a judge is an explanation where it is acceptable in the society related to the regulation on concrete situation. This interpretation method is a facility used to find judicial meaning ${ }^{10}$. Fitzgerald, as quoted by Satjipto Rahardjo, stated that majority of interpretation can be divided into differentiation named literal interpretation and functional interpretation. Literal interpretation used words from the regulation as the only reference. On another words, explicit interpretation is an interpretation with litera legis. Meanwhile, functional interpretation is also called free interpretation which does not always attach with words (litera legis). The functional interpretation, by using various references, tries to dig a real purpose of regulation so that satisfying explanation achieved ${ }^{11}$.

Sudikno Mertokusumo identified at least eight common interpretation methods, they are:

a. Grammatical interpretation;

b. Systematic or logical interpretation;

c. Historical interpretation;

d. Theological and sociological interpretation;

e. Comparative interpretation;

f. Anticipative and futuristic interpretation;

g. Restrictive interpretation; and

h. Extensive interpretation ${ }^{12}$.

Besides, in constitutional law bibliography, constitutional is also known as constitutional interpretation method. Philip Bobbitt identified six methods of constitutional interpretation as follows:

a. Historial argument;

b. Textual argument;

c. Doctrinal argument;

d. Prudential argument;

e. Structural argument; and

f. Ethical argument. ${ }^{13}$

${ }^{9}$ Ibid, p. 142.

10 Tim Penyusun Hukum Acara Mahkamah Konstitusi. (2010). Hukum Acara Mahkamah Konstitusi. Sekretariat Jenderal dan Kepaniteraan Mahkamah Konstitusi Republik Indonesia : Jakarta, p. 67.

11 Satjipto Rahardjo. (1982). Ilmu Hukum. Penerbit Alumni : Bandung, p. 126.

12 Sudikno Mertokusumo. (2007). Penemuan Hukum, Sebuah Pengantar. Liberty : Yogykarta, p. 57-64.

13 Philip Bobbitt. (1982). Constitutional Fate, Theory of the Constitution. Oxford University Press : New York, p. 9-93. 
Ahmad Rifai, identified at least eleven methods of interpretation: grammatical, historical, systematic, theological or sociologic, comparative, futuristic or anticipative, restrictive, extensive, authentic, interdisciplinary, and multidisciplinary ${ }^{14}$. Ahmad Rifai also identified at least four method of legal construction, such as argumentum per analogium (analogy), argumentum a contrario, legal narrowing or concreting, and legal fiction ${ }^{15}$. The constitution is an expression of will own by state which is trusted to formulate the law. Therefore, it is acceptable to track the meaning in constitution according to what has formulated by the lawmaker. In short, it is the interpretation and the history behind it ${ }^{16}$.

It is important to reconsider mistakes occurred in making interpretation before doing interpretation on words in product of constitution, because it will create good impact in the implementation of law. This consideration confirms the maxim "expressum facit cessare tacitum", which means that words being firmly said would stop the search for meaning in the constitution. Therefore, in making interpretation, it is better to avoid three logical fallacies: First, semantic ambiguity; happened when there is open texture; words are formulated in very common way so that it creates ambiguity in their implementation. Thus, detail formulation is different with what is ambiguous; Second, syntactic ambiguity; occurred by the use of the word "or", "and", "all", etc. Ambiguity may also happen when constitution's maker sends unclear message on the purpose of making it. In other words, the maker has no frim concept and clear vision in formulating new regulations ${ }^{17}$.

Ian McLeod said that contextual interpretation or contextualism describes three basic principles as proceeding:

a. Noscitur a sociis; something is recognized from what is associated with it. Thus, a word should gain meaning by its suite..

b. Ejusdem generis; based on genus. It means that a word is limited by specific meaning in its group. For example, the meaning of "rechtmatigheid" in administrative law would not be interpreted the same way if it in civil law or criminal law principle.

c. Expressio unius exclusio alterius; specific concept used for one thing would not be appropriate with another. For example, if rechtmatigheid concept had been implemented in state administrative law, it would not suitable to be used for circle in civil law or criminal law ${ }^{18}$.

The question is, in proposed judicial review, what method of interpretation is used by judges of the constitutional court in interpreting constitution toward the constitution of the republic of Indonesia? Judges served in constitutional court have freedom to utilize and elaborate constitutional interpretation method used to examine regulation toward the Constitution of the Republic of Indonesia year 1945 in accordance to their own understanding. Not only that the constitutional interpretation was not regulated in positive law, judges have independency in making new law discovery (rechtsvinding). Therefore, the interpretation method used by judges in constitution court is basically determined by each cases displayed at the moment. The constitutional court, as an absolute constitutional interpreter, needs to set freedom from the repression of law

\footnotetext{
14 Ahmad Rifai (2010). Op.Cit, p. 62-72.

15 Ibid,-. p. 75-85.

16 Satjipto Rahardjo (1982). Op.Cit, p. 133.

17 Ibid, p. 129.

18 Ahmad Rifai (2010). Op.Cit, p. 62.
} 
text. The constitutional court, in doing the interpretation, should better in have substantial justice orientation instead of staying at procedural justice orientation ${ }^{19}$.

\section{The Constitutional Interpretation on Natural Resource}

Constitutional interpretation is the interpretation of law in the constitution ${ }^{20}$. According to Saldi Isra, et all, as quoted by Muhammad Ali Syafaat, et all, the interpretation designed in constitutional review used two great flows of classified interpretations named as originalist and non-originalist approach. The two classified constitutional interpretations are described as the following: ${ }^{21}$

\subsection{The Originalist Approach}

Originalist, in the interpretation of constitutional text, focuses more on comprehension and constitutional goal of ideas offered by constitutional maker. Some of the interpretations approach used are:

a. Textualist or strict constructionism. For textualist, text plays as the main reference used by judges in resolving the lawsuit which related to constitutional matter. Experts also claimed textualist as strict constructionism where decision made from what is stated in text of written constitution, as long as there is ambiguity of meaning in the chosen words.

b. Historical or original intents. Followers of this belief assure that every decision made by judges should be based on meaning in words or sentence which discovered through historical analysis in the arrangement and ratification of law or constitution.

c. Functional or structural. Functionalist believes that adjudication made by judges should be based on deeper analysis on structure and what it entails toward the history behind the law referred to. It also functions as tool to look up for its connectivity as system harmonization.

\subsection{Non-originalist Approach}

Group of people who are against the view of originalist are ones who call themselves ad modernist or instrumentalist. Modernist believes that using constitution as an approach has to be adjusted with modern or recent situation. Modernist also believes that it is impossible to evaluate constitution only from the history of how it was made. Some interpretations approaches used are:

a. Doctrinal or Stare Decisis. This belief put the idea that adjudication should be based on familiar practices or views from professional in the law field, such as legislatives, executives or form the existed adjudication (jurisprudence), based on the metadoctrine from views in a decision which is made by implementing principles used by judicature in giving adjudication. In other words, it plays not only as a review but also as a law (normative).

19 Mahrus Ali. (2010). Mahkamah Konstitusi dan Penafsiran Hukum Yang Progresif. Jurnal Konstitusi, Mahkamah Konstitusi Republik Indonesia, 7(1), 67-90. doi: https://doi.org/10.31078/jk\%25x

20 Muhammad Ali Syafaat, et all. (2017). Pola Penafsiran Konstitusi dalam Putusan Mahkamah Konstitusi Periode 2003 - 2008 dan 2009 - 2013. Jurnal Konstitusi, Mahkamah Konstitusi Republik Indonesia, 14(2), 234-261. doi: https://doi.org/10.31078/jk1421

${ }^{21}$ Ibid, p. 240-241. 
b. Prudential. Prudentialist believes that adjudication made should be based on external factors of law or particular interests contains in every case such as political power abuse. This view rejects things that may bring bias into judge's personal consideration by deliberating external factors of judicature. This concept is remaining as the main reason or foundation in doctrinal approach.

c. Equitable or Ethical. According to Equitable, a decision should be based on the sense of justice, balance of interests, and what is right and wrong, without looking up at what was written as regulation in law 22 .

If these two big flows of classified interpretation are made into table, the differences would be displayed as described in the Table 1 .

Tabel 1. Groups of Constitutional Interpretation ${ }^{23}$

\begin{tabular}{|c|c|c|}
\hline Interpretation & Sub-interpretation & Qualifications \\
\hline \multirow{3}{*}{ Originalist } & Textualist & Constitutional text as the main reference \\
\hline & $\begin{array}{l}\text { Historical/Original } \\
\text { Intent }\end{array}$ & $\begin{array}{l}\text { Meaning is generated from the analysis on } \\
\text { history of the formulation }\end{array}$ \\
\hline & Functional/Structural & $\begin{array}{l}\text { Constitutional structure and its entailments } \\
\text { along with the history of its formulation on } \\
\text { creating harmony in the system }\end{array}$ \\
\hline \multirow{3}{*}{ Non Originalist } & Doctrinal & $\begin{array}{l}\text { Based on what is being accepted in law and is } \\
\text { being implemented in practice }\end{array}$ \\
\hline & Prudential & Accept the non-law factors \\
\hline & Ethical/Natural Law & $\begin{array}{l}\text { The sense of justice, balance of interests, and } \\
\text { what is right and wrong }\end{array}$ \\
\hline
\end{tabular}

According to Richard H. Fallon Jr., "when attempting a normative defense of originalist principles, prominent originalist characteristically begin by appealing to an ideal of the rule of law ${ }^{24}$. In addition, Fallon, on the whole, originalist dislikes fluidity. Among their principal aims is determinate law that would bind courts as well as legislatures ${ }^{25}$. In interpreting the constitution, Lieber elaborated eleven constitutional hermeneutics principles as follows:

1. It is not decent to build strong argument over insecure base (for instance, one's opinion about a word).

2. It is useless to talk too much or saying very detail. Tidak ada gunanya kita memberikan penuturan yang berkepanjangan atau memberikan penyebutan yang terlalu rinci. Good belief and consciousness are what crucial the most.

3. Public prosperity is the highest law in every state, salus populi suprema lex. There is no construction against the law of all law.

4. In common cases, constitution should have been carefully and precisely interpreted.

5. The stronger the character of both formal and organized of a constitution is, the more precise is the construction should be.

22 Mengenai pola penafsiran konstitusi ini, lebih lengkapnya dapat dilihat di Saldi Isra, et all. (2010). Perkembangan Pengujian Perundang-undangan di Mahkamah Konstitusi (Dari Berpikir Hukum Tekstual ke Hukum Progresif). Jakarta: Sekretariat Jenderal dan Kepaniteraan Mahkamah Konstitusi, p. 58-69.

${ }^{23}$ Muhammad Ali Syafaat, et all. (2017). Op.Cit.

${ }^{24}$ Richard H. Fallon Jr. (2001). Implementing The Constitution. Cambridge : Hardvard University Press, p. 19.

25 Ibid, p. 14. 
6. All regulations related to what existed before, is demanding special attention to be implemented in constitutional construction.

7. Transcendence construction (built in higher principle beyond text) can sometimes be a reference (does not support the abusive of power), while staying aware that it may become a way for undesirable situation happens.

8. We can freely interpret law (as long as all parties are benefited) compared to when we have to interpret the constitution (due to the number of people and interests being involved).

9. Seek the good spirit of constitution and implement the interpretation with strong beliefs. We use the spirit for creating public prosperity and keep the instrument updated to balance modern demand.

10. If there is a provision about the official changing of constitution, the needs related to it (discussed in point 9) would be very limited. Nevertheless, it would still be there.

11. If the constitution admits the rights of citizen, people's freedom of life can be manifested by precise interpretation as the provision. Everything related with power should accurately be interpreted; everything in relation to people's security and individual protection should be interpreted thoroughly and covers all parties ${ }^{26}$.

According to Lilis Mulyani, constitutional court adjudication on natural resource is contributed as compass for making discernment and interpretation toward Section 33 of constitution of the republic of Indonesia year 1945, based on the amendment ${ }^{27}$. It means that the main interpretation of constitutional court in examining the regulation on natural resource is being concentrated on the interpretation of Section 33, Constitution of the Republic of Indonesia year 1945. The dynamic of global economic development helps influencing the view of the regulation on natural resource in Indonesia. As a result, the regulation on natural resource has been shifted into global market era or in neo-liberal design.

According to Ahmad Redi, some laws are reviewed based on Section 33 verse (3), Constitution of the Republic of Indonesia year 1945 as the touchstone, especially to what the so-called "own by the state". The phrase "own by the state" has become sacred in the widespread of recent economic liberalization. This also creates liberalization on natural resource, hiding behind liberal law. The siege of neoliberalism on controlling natural resource may possible be manifested in law. Therefore, as a guardian of Section 33 constitution of the republic of Indonesia year 1945 which puts a high honor on the economic community, the role of constitutional court is therefore, become very crucial. The siege of liberalization may also be a threat, that it becomes dangerous if controlling on the natural resource (economic commodity) is betraying content of constitution of republic of Indonesia 1945, in particular Article 33 which acts as the principle of keeping the natural resource owned by the state and is hopefully creating prosperity to countless people ${ }^{28}$.

\footnotetext{
26 Gregory Leyh, et all (2008). Op.Cit, p. 144-145.

27 Lilis Mulyani. (2008). Pengelolaan Sumber Daya Alam di Mata Mahkamah Konstitusi : Analitis Kritis atas Putusan Mahkamah Konstitusi tentang Sumber Daya Alam. Jurnal Masyarakat dan Budaya, Lembaga Ilmu Pengetahuan Indonesia, 10(2), 65-88, doi: http://dx.doi.org/10.14203/jmb.v10i2.217

28 Ahmad Redi. (2015). Dinamika Konsepsi Penguasaan Negara Atas Sumber Daya Alam. Jurnal Konstitusi, Mahkamah Konstitusi Republik Indonesia, 12(2), 401-421. doi: https://doi.org/10.31078/jk12210
} 
If the constitutional interpretation is seen as the interpretation on regulations in constitution, the constitutional interpretation on natural resource is the interpretation toward constitution which closely related to natural resource regulation. Product of law, focuses on controlling natural resource and it great impact on citizen of Indonesia, should have been being prioritized more when proposing judicial review at constitutional court. The debate on constitutional interpretation on natural resource still sits between originalist and no originalist view. But for sure, we do not have to create demark line between the two, because between them, there is a strong connection used in interpreting the management of natural resource in Indonesia.

Basically, the constitutional interpretation may become modern depending on the adjustment of recent situation (non originalist), but it should never break the original purpose of constitution on behalf of the maker (originalist). On the other hand, the interpretation on natural resource should better use the originalist interpretation, so that it will not change the origin of substantial controlling intention. Nonetheless, the non originalist is still usable even if it is limited only for technical level because constitution is believed to continue adapting with the developing era.

According to Pan Mohamad Faiz"29, "Nowadays, constitution is assumed to no longer an inanimate document, but it is more that. It appears and functions as basic principles in organizing a state, thus it has to be enliven to update the development of period time (the living constitution)". Therefore, the constitutional interpretation on natural resource with originalist's method at least highlights two important points:

First, keeping the dignity of the natural resource management as stated in Section 33 constitution of the republic of Indonesia year 1945, continue following the main goal and the dream (rechtside) of the lawmaker. According to Taufiqurrohman Syahuri 30 "Constitutional spirit, in particular the spirit connecting with Article 33 constitution of the republic of Indonesia 1945 will be elaborated with political law approach in terms of historical story behind the making of constitution of the republic of Indonesia 1945". Thus, originalist approach has always put ahead historical aspects in order to explain the original intention of the constitution. Second, protecting the state so that it can safely runs the role of controlling and managing natural resource. Also as the protector of people and state's sovereignty on natural resource sector. Free market has reinforced the state to lessen, even to cut the role state in managing its own natural resource. Ria Casmi Arrsa31, said that, "law development in natural resource sector is extended fast in the middle of rapid infestation demanding for law assurance for entrepreneurship to run economic practices on the exploration of natural resource in Indonesia".

Thing to consider is that law assurance is essential for the state, but creating prosperity for its citizen is away more important. Free market is unstoppable, but the state has power to control and manage its own natural resource. Quoted in Herdiansyah Hamzah32, "principally, the management of natural resources cannot be separated from the development of the global market, but it does not mean that our country must give in and follow the design of free-market competition. But when our country is against both of these options, the

29 Pan Mohamad Faiz. (2016). Perlindungan Terhadap Lingkungan Dalam Perspektif Konstitusi. Jurnal Konstitusi, Mahkamah Konstitusi Republik Indonesia, 13(4), 766-787. doi: https://doi.org/10.31078/jk1344

30 Taufiqurrohman Syahuri. (2012). Politik Hukum Perekonomian Berdasarkan Pasal 33 UUD 1945. Jurnal Konstitusi, Mahkamah Konstitusi Republik Indonesia, 9(2), 243-258. doi: https://doi.org/10.31078/jk\%25x

31 Ria Casmi Arrsa. (2015). Telaah Sosiolegal Terhadap Terwujudnya Kedaulatan Hak Atas Sumber Daya Air. Jurnal Rechtsvinding, Badan Pembinaan Hukum Nasional, 4(2), 219-235.

32 Herdiansyah Hamzah. (2016). Legal Policy of Legislation in the Field of Natural Resource in Indonesia. Hasanuddin Law Review, 2(1), 108-121. doi: http://dx.doi.org/10.20956/halrev.v1i1.218 
choice for sure, has to be engaged with the management practice that affirms our nation's economic independency".

Nevertheless, in building the constitutional interpretation on natural resources, judges in institutional court should never neglect other principles such as, firstly, the interpretation does not simply focus on grammatical meaning which tends to be textual. Judges in institutional court, therefore, should arouse original intention inside the text stated in constitution of the republic of Indonesia year 1945. Secondly, judges in institutional court, have to take into serious consideration on the constitutional interpretation instead of statutory interpretation. Since a judge, sometimes, does not use constitutional interpretation but using statutory interpretation instead, and in particular adjudication, judge do law interpretation alone in replying the lawsuit or norm being asked. On this level, decision made by the judges are often becoming a spotlight seen by many people because the constitution of the republic of Indonesia year 1945 is no longer taken as primary text source in interpreting the law, eventhough both interpretations have similar purpose, which is to find meaning from a particular norm. On the other hand, it is found that both are different in terms of objects being interpreted, which are norms in constitution of the republic of Indonesia year 1945 and norms of law.

Hence, the interpretation of law by the court is for sure cannot be neglected. Nonetheless, thing needs to be fully considered is that the final interpreter of the constitution $^{33}$ is always be the main function of the court. Thus, it is clear that the constitutional adjudications related to the management of natural resources is becoming political law sets as the main reference of law making in national legislation process ${ }^{34}$. Thirdly, the constitutional interpretation on natural resources is absolute. It should be goal oriented, which are managing the natural resources of Indonesia so it can provide huge and significant prosperity for the people. The constitutional court has formulated four measurements tool to decide whether a law or law act is aimed at giving huge prosperity for people as stated in Article 33 verse (3), constitution of the republic of Indonesia year 1945. The four measurements tool are: (i) Empat tolak ukur tersebut antara lain: (i) natural resources benefited for people, (ii) the utilization of benefits on natural resources for people, (iii) people's participation level in determining the benefits of natural resources, and (iv) respect for people's inherited rights in the utilization of natural resources ${ }^{35}$. Therefore, the principle of "huge benefit for people" is the main desired goal of the management on natural resources using term stated as "state owning rights" 36 as the instrument.

\section{Conclusion}

Judges served in constitutional court have freedom to utilize and elaborate constitutional interpretation method used to examine regulation toward the constitution of the republic of Indonesia 1945 in accordance to their own understanding. Not only that the constitutional interpretation was not regulated in

33 Bisariyadi, et al. (2016). Penafsiran Konstitusi Dalam Pengujian Undang-undang Terhadap Undang-undang Dasar. Jakarta: Kepaniteraan dan Sekretariat Jenderal Mahkamah Konstitusi Republik Indonesia, p. viii.

34 Irfan Nur Rachman. (2016). Politik Hukum Pengelolaan Sumber Daya Alam Menurut Pasal 33 UUD 1945. Jurnal Konstitusi, 13(1), 195-212. doi: https://doi.org/10.31078/jk1319

35 Bisariyadi, et all. (2016). Op.Cit, p. 66.

36 Suyanto Edi Wibowo. (2015). Memaknai Pasal 33 Undang-undang Dasar Negara Republik Indonesia Tahun 1945 Perihal Penguasaan Oleh Negara Terhadap Sumber Daya Alam. Jurnal Legislasi Indonesia, 12(4), 157. 
positive law, judges have independency in making new law discovery (rechtsvinding), Therefore, the interpretation method used by judges in constitution court is basically determined by each cases displayed. On the other words, the interpretation method used by judges in constitution court is depending on the lawsuit reported in judicial review.

Constitutional interpretation on natural resource has to be based on original (originalist) interpretation rooted by original intent or text stated in the constitution of the republic of Indonesia year 1945, along with document of disagreement on its formulation (memorie van toelichting). Original interpretation is aimed at avoiding the shift at the origin of substantial intention of natural resources management. Nevertheless, non-originalist interpretation will remain usable, but it is limited only for technical level, so that natural resources management will stay updated while keeping the basic foundation of natural resources management as firmly stated in constitution.

\section{References}

Books

Ali, Achmad. (1993). Menguak Tabir Hukum (Suatu Kajian Filosofis dan Sosiologis). Jakarta: Candra Pratama.

Bisariyadi, et all. (2016). Penafsiran Konstitusi Dalam Pengujian Undang-undang Terhadap Undang-undang Dasar. Jakarta : Kepaniteraan dan Sekretariat Jenderal Mahkamah Konstitusi Republik Indonesia.

Philip Bobbitt. (1982). Constitutional Fate, Theory of the Constitution. Oxford University Press : New York.

Fallon, Richard H. Jr. (2001). Implementing The Constitution. Cambridge : Hardvard University Press.

Huda, Ni'matul dan Nazriyah, R. (2011). Teori \& Pengujian Peraturan PerundangUndangan. Bandung : Penerbit Nusa Media.

Leyh, Gregory, et all. (2008). Hermeneutika Hukum. Bandung : Penerbit Nusa Media.

Rahardjo, Satjipto. (1982). Ilmu Hukum. Bandung : Penerbit Alumni.

Rifai, Ahmad. (2010). Penemuan Hukum Oleh Hakim Dalam Perspektif Hukum Progresif. Jakarta : Sinar Grafika.

Salman, Otje dan Susanto, Anthon F.. (2005). Teori Hukum (Mengingat, Mengumpulkan dan Membuka Kembali). Bandung : PT. Refika Aditama.

Susanto, Anthon F. (2010). Ilmu Hukum Non Sistematik, Fondasi Filsafat Pengembangan Ilmu Hukum Indonesia. Yogyakarta : Genta Publishing.

Tim Penyusun Hukum Acara Mahkamah Konstitusi. (2010). Hukum Acara Mahkamah Konstitusi. Jakarta: Sekretariat Jenderal dan Kepaniteraan Mahkamah Konstitusi Republik Indonesia. 
Journal Articles

Ali, Mahrus. (2010). Mahkamah Konstitusi dan Penafsiran Hukum Yang Progresif. Jurnal Konstitusi, Mahkamah Konstitusi Republik Indonesia, 7(1), 67-90. doi:https://doi.org/10.31078/jk\%25x

Arrsa, Ria Casmi. (2015). Telaah Sosiolegal Terhadap Terwujudnya Kedaulatan Hak Atas Sumber Daya Air. Jurnal Rechtsvinding, Badan Pembinaan Hukum Nasional, 4(2), 219-235.

Edi Wibowo, Suyanto. (2015). Memaknai Pasal 33 Undang-undang Dasar Negara Republik Indonesia Tahun 1945 Perihal Penguasaan Oleh Negara Terhadap Sumber Daya Alam. Jurnal Legislasi Indonesia, 12(4), 1-57.

Faiz, Pan Mohamad. (2016). Perlindungan Terhadap Lingkungan Dalam Perspektif Konstitusi. Jurnal Konstitusi, Mahkamah Konstitusi Republik Indonesia, 13(4), 766-787. doi: https://doi.org/10.31078/jk1344

Hamzah, Herdiansyah. (2016). Legal Policy of Legislation in the Field of Natural Resource in Indonesia. Hasanuddin Law Review, 2(1), 108-121. doi:http://dx.doi.org/10.20956/halrev.v1i1.218

Mulyani, Lilis. (2008). Pengelolaan Sumber Daya Alam di Mata Mahkamah Konstitusi : Analitis Kritis atas Putusan Mahkamah Konstitusi tentang Sumber Daya Alam. Jurnal Masyarakat dan Budaya, Lembaga Ilmu Pengetahuan Indonesia, 10(2), 65-88, doi: http://dx.doi.org/10.14203/jmb.v10i2.217

Syafaat, Muhammad Ali, et all. (2017). Pola Penafsiran Konstitusi dalam Putusan Mahkamah Konstitusi Periode 2003 - 2008 dan 2009 - 2013. Jurnal Konstitusi, Mahkamah Konstitusi Republik Indonesia, 14(2), 234-261. doi: https://doi.org/10.31078/jk1421

Syahuri, Taufiqurrohman. (2012). Politik Hukum Perekonomian Berdasarkan Pasal 33 UUD 1945. Jurnal Konstitusi, Mahkamah Konstitusi Republik Indonesia, 9(2), 243-258. doi: https://doi.org/10.31078/ik\%25x

Rachman, Irfan Nur. (2016). Politik Hukum Pengelolaan Sumber Daya Alam Menurut Pasal 33 UUD 1945. Jurnal Konstitusi, Mahkamah Konstitusi Republik Indonesia, 13(1), 195-212. doi: https://doi.org/10.31078/jk1319

Redi, Ahmad. (2015). Dinamika Konsepsi Penguasaan Negara Atas Sumber Daya Alam. Jurnal Konstitusi, Mahkamah Konstitusi Republik Indonesia, 12(2), 401-421. doi: https://doi.org/10.31078/jk12210

\section{Conflict of Interest Statement:}

The author(s) declares that the research was conducted in the absence of any commercial or financial relationships that could be construed as a potential conflict of interest.

Copyright (C) 2019 HALREV. All rights reserved. 